\title{
MORAL EDUCATION IN M. QURAISH SHIHAB PERSPECTIVE (ANALYSIS STUDY OF TAFSIR AL-MISBAH)
}

\author{
Mustaqim \\ e-mail: mustaqim_safar@gmail.com
}

\begin{abstract}
The purpose of this research is to find out the method of M. Quraish Shihab interpretation on moral verses in the tafsir (interpretation) of al- Misbah, and how is the concept of moral education according to M. Quraish Shihab in the tafsir al-Misbah. This thesis research method used literature review. Data collection techniques were through the process of organizing and selection where the data was organized and selectively managed according to the criteria based on content analysis. Then the data was managed as it is by the maudhu'i method. The mauhu'i method is a method that discusses and analyzes tasfir of moralverses, so that it becomes a unified whole. The results showed that in elaborating M. Quraish Shibah's thoughts on moral verses, he was more likely to use the Tahlily method in interpreting the contents of the verse. His ability of high Arabic language is very visible when discussing the meaning of words in the Qur'an. This work is also rich in references, so the discussion is very broad and detailed, but still in the corridor needed by an interpretation. The components of moral education in the M. Quraish Shihab's opinion can be summarized as follows: 1). The purpose of moral education is the achievement of the goal of human creation as the caliph of Allah in the world. 2). The learning method used in conveying moral education is a method of mental exercise, habituation, exemplary and a healthy environment. 3). The correlation between M. Quraish Shihab's moral education and Islamic education is that the substance of Islamic education that is moral education itself.
\end{abstract}

Keywords: Education, Morals and Tafsir al-Misbah

\section{A. INTRODUCTION}

Education has a variety of definitions and many figures who provide terminological definitions according to their points of view so that they become diverse 
as well. In the Indonesian language dictionary, education is defined as a process of changing the attitude and behavior of a person or group in an effort to mature humans through training and teaching efforts (processes, actions, and ways of educating). ${ }^{1}$ Then more specifically the education by Ali Saifullah is defined as a process of growth in which each individual is assisted to develop their abilities, talents, skills, and interests. ${ }^{2}$ Whereas in the Republic of Indonesia Law on National Education, education is defined as conscious and planned effort to realize the learning atmosphere and learning process so that the students actively develop their potential to have religious spiritual strength, selfcontrol, personality, intelligence, noble character, and skills what he needs, society, nation and country.

Morals are one of the treasures of Muslim scholars whose presence is needed to organize human life. The main task of sending the Messenger of Allah on earth to perfect human moral is one proof that morality is a very important thing to consider before arranging the other side of life.

The importance of this moral study can be felt today, where people are faced with serious moral and moral problems. Life practices that deviate from both religious norms and existing social norms become a common sight. News about all kinds of sadistic acts that cause a lot of harm to others, corruption, muggings, robberies, murders, rapes, and deprivation of human rights always ring every day even every second. Sophisticated science and technology will not be able to answer these problems, if they not accompanied by structuring in the field of mental and spiritual morals. The most effective mental and spiritual arrangement is through education, both in school and out of school. While the most effective way of conveying moral messages is through examples of behavior that should be provided by community leaders, religious leaders, parents, teachers, and leaders.

According to M. Quraish Shihab the word 'moral' in religious teachings cannot be equated with ethics. If ethics is only limited to manners among fellow human beings, and only relates to outward behavior, morality is broader in meaning than has been stated which includes several things which are not external, such as those relating to the inner

\footnotetext{
${ }^{1}$ WJS Poerwadarminta, Kamus Besar Bahasa Indonesia, (Jakarta: Balai Pustaka: 1993), 38

2 Ali Saifullah, Antara Filsafat Dan Pendidikan, (Surabaya: Usaha Nasional, tt.), 135
} 
attitude and mind. Akhlak diniah (religion) covers various aspects starting from morality unto God to fellow creatures (humans, animals, plants and lifeless objects). ${ }^{3}$

Moral education is a major problem that has always been a human challenge throughout its history. The history of the nations both enshrined in the Qur'an such as the peoples of 'Ad, Tsamud, Madyan and Saba' and those obtained in history books shows that a nation will be strong if its morals are strong and on the contrary, a nation will collapse if its morals are damaged.$^{4}$

Moral education is the other side of the Prophet's education which is the soul of Muslim education in the next stage. Muslim education experts agree that the goals of education and teaching are not limited to meeting the brains of students with various kinds of knowledge. The main purpose of education is to educate students' character and spirit, instill a sense of fadilah and prepare them in a holy life. ${ }^{5}$ In this case the Prophet Muhammad himself was a source of inspiration for moral education, the journey of Muhammad's life became evidence of the moral elevation of an educator in the community of a new nation emerging from the destruction of morals and civilization.

According to Rashid Ridha, as quoted by Harun Nasution, the Qur'an contains guidance, namely the basics of religion, guidance, laws, instructions on the use of physical power and reason for human benefit. ${ }^{6}$ The Qur'an was revealed to Muhammad in two separate places namely Mecca and Medina, the verses can be classified into two parts; verses of Makkiyyah and Madaniyyah.

The concept of Makkiyyah and Madaniyyah brings consequences to the existence of special characteristics that distinguish between the two. The contents of the verses of the Makkiyyah and Madaniyyah verses are basically the content and material taught by the Prophet to the generation of friends. Thus, the Prophet's educational material is the Qur'an itself which is the basis of Muslim education, or in other words, the Prophet's education is the Qur'an education. The preaching of the Messenger of Allah during in Mecca was specifically aimed at the problem of faith and this was done during the 13

\footnotetext{
${ }^{3}$ M. Quraish Shihab, Wawasan al-Qur'an (Tafsir Maudhu'i atas pelbagai Persoalan Umat), (Jakarta: Mizan), 261

${ }^{4}$ Lihat al-Siba'i Bayumi, et al., al-Adab wa al-Nusus (Kairo: Dar Nahdah Mishr, tt), 255

5 Imam Malik ibn Anas, al-Muwatta' (Beirut: Dar al-Fikr, 1989), Cet.-1, 48; Muslim, Sahih Muslim, jld. I, (Beirut: Dar al-Fikr, 1989), 182; al-Bukhari,1, 134

6 Harun Nasution, Islam Rasional (Bandung: Mizan, 1996), Cet: 4, 51; QS. Al-Nahl: 89, QS. Al- An'am: 38
} 
years of the prophetic period. Then the results achieved by the Companions of the prophet can show perfect quality. At that time the rules of other laws that governed private and community life were not revealed, such as mu'amalah, fasting and others. Even the command of salat was revealed by Allah to the Prophet before moving to Madinah. It is recognized here that the role of the faith is very important in the formation of humans and society. The Messenger of Allah was sent to perfect human morals. But this perfect character cannot be realized without relying on the foundation of faith because of a firm faith. If the faith can already be realized in charity then automatically human morality will be able to follow it.

To further explain the notion of moral concepts in the Qur'an, the interpretation of M. Quraish Shihab in his phenomenal, it will be used Tafsir (interpretation) alMisbah, because he is one of Indonesia's contemporary mufassir who is still productive today. He is indeed very competent because the results of his works although there are interpretations that are considered very controversial, for example the headscarf problem.

\section{B. RESEARCH METHODS}

This study was a library research by examining various related data, both from primary data sources and supporting data sources (secondary sources). Primary data sources were works written by M. Quraish Shihab who is the author of Tafsir al-Misbah. The supporting data sources (secondary sources) were the writings of others who write about the concept of moral education.

The data was taken from the main sources and supporting sources related to the theme: The Concept of Moral Education according to M. Quraish Shihab (review of Tafsir al-Misbah) through literature review. The acquisition was through the process Organizing and Selection where the data was organized and managed selectively according to categorization based on Content Analysys. Then the data was managed as it was using the method maudu'iy. The method maudu'iy is a method that discusses and analyzes interpretations of moral verses so that they become a unified whole. ${ }^{7}$

The data obtained was raw material that must be analyzed and compiled more easily in obtaining meaning and interpretation, seeing the many methods that can be used

\footnotetext{
${ }^{7}$ M. Quraish Shihab, Membumikan Al-Qur'an, (Bandung: Mizan, 1998), 220
} 
in the study of a science, the researcher used several methods relevant to the above study themes, among others:

a. Thematic interpretation methods (Interpretation Maudu'iy)

In accordance with the term, this method used an approach by choosing a theme or title that has been set. All related verses are collected. Then, they are reviewed in depth and thoroughly from various aspects related to it. ${ }^{8}$

b. Deductive Method

Deductive is a way of thinking that departs from general events, and starts with the knowledge that is to assess specific events. ${ }^{9}$

c. Inductive Method

Inductive is a way of thinking that departs from more specific facts, concrete events are then drawn to generalizations that have general characteristics. ${ }^{10}$

d. Descriptive Method

Descriptive method is to describe the entire data of research results obtained in detailed discussion. So, by this method it is expected that there is a unity between language and mind. This new understanding will be strong if it is felt. Understanding that is based on its specificity and concreteness can be evidence for general understanding.

e. Comparative Method

Comparative method is a method used to compare data drawn in a new conclusion. Comparasion itself comes from the English language, which is compare which means to compare to find two or more concepts. Clarified by Winarno Surahmad that the comparative method is an investigation that can be carried out by examining the relationship more than a similar phenomenon which shows the elements of equality and difference.

\section{RESEARCH RESULTS AND DISCUSSION}

\section{Method of Tafsir al-Misbah}

\footnotetext{
${ }^{8}$ Nasaruddin Baidan, Metodologi Penafsiran al-Qur'an, (Yogyakarta: Pustaka Pelajar Offset, 1998), 151

${ }^{9}$ Sutrisno Hadi, Metodologi Research I, (Yogyakarta: Andi Offset, 1973), 42

${ }^{10}$ Ibid, 49
} 
In interpretation of Tafsir al-Misbah, the method of interpretation used by M. Quraish Shihab is the method tahlily because he wants to reveal all sides of the Qur'an in detail so that the instructions can be explained and understood by the readers. For this purpose, inevitably, the writer must use that method in his interpretation. This is what should be an alternative for M. Quraish Shihab, in accordance with his purpose and desire to interpret the entire contents of the Qur'an.

Beside these methods, other various methods are also used. When viewed from the method of explanation, the method of muqarin is often applied. In terms of the extent of the interpretation, the method used is itnabiy, the, and when viewed in terms of its source, the method often used is ma'thur, $r a^{\prime} y$, or both of them.

In this connection, Muhammad Quraish Shihab used the term a method of material delivery. According to him, al-Qur'an al-Karim views, in directing his education to humans, it faces and treates the creature in line with the elements of its creation; body, mind and soul. In other words: "Directing him to become a complete human being." Therefore, the methods in building moral are as follows: ${ }^{11}$

a. Soul treatment

Human is blessed with positive and negative potential. In every person there is a battle between conscience (light) and zulmani (darkness). This is human nature. Conscience is led by a combination of reason and qalb (rushd), while zulmani is led by the nafs. Lust has weaknesses that must be used by soul processors. He is like a baby, will not stop feeding. What is needed by the mother is the determination to wean her baby. Indeed, at the beginning it was very difficult to do, both for mother and lust, but if determination is maintained, weaning must succeed.

In the context of mental processing and controlling lust, we find practices that some people might consider to be strange practices. The Prophet Muhammad, for example, plastered the stone in his stomach so that the screams of his appetite decreased. Abu Bakr al-Siddiq ra. once slipped a small stone in the side of his mouth so that he thought diligently before speaking, Umar ra. Carrying a vessel of water on his back with the intention of defeating his lust for his position as Amir al-Mu'minin (head of state). The Sufis also known has tips that nyleneh (strange) in the context of life coaching. Someone is not given a diploma, namely permission to practice a

\footnotetext{
${ }^{11}$ M. Quraish Shihab, Menabur Pesan Ilahi (Jakarta: Lentera Hati), 354-360
} 
practice, except after going through various practical exams, which ends with a test that is not intended to prove its superiority, or what is in Higher Education as $a$ promotion test; an examination that does not reduce his academic rights / achievements, but at the same time leads him to the realization that what he does or does not know is still far more than what he knows. This can eventually erode intellectual arrogance and awaken to continue climbing and climbing.

b. Habituation

Habituation begins with a genuine effort to force yourself, even if it is necessary to make activities that are considered good with the aim of forming a character, not because of hypocrisy. Imam Ghazali advised someone who was arrogant to get used to doing activities carried out by those who were moral and considered to have a high social status. The expert also, for example, recommended caressing the head of an orphan. Habits that give birth to skills that are repeated and which are carried out consciously - in the conscious region (celebral cortex) will switch to the subconscious brain (basal ganglia) so that it forms character, namely activities carried out automatically, due to a very deep mental drive. When that proved the expression "Being capable because of habit".

Some Contemporary experts, such as Paul G. Stolz, suspect that forming new habits, even changing Adversity Quotient (AQ) can be done in an instant. This view may be true in matters of a material nature or at least concerning the mind or frame of mind, but not applicable for changing behavior or creating new behavior is evident from our recognition of the importance and goodness of justice or bad and cruel persecution, but not a little of those who admit it doesn't do good and instead do the bad.

Indeed, an explanation of good and evil is needed to change views, but that is not enough. He must be accompanied by habituation. Some experts determine a certain time to form a character. Steven R. Covey, for example, calls 30 days. In addition, many prophetic traditions that call 40 days.

c. Exemplary

Exemplary is needed because not infrequently abstract values are not understood, even the beauty and benefits of most people do not appear. Abstract things are explained by concrete and sensory parables. Exemplary in this case exceeds the 
parable in its function and role. That is also the reason why exemplary is needed and has a very large role in transferring traits and characters.

In campus life, religious values / Pancasila (five basics), whose first principle is the one and only God, must be realized in the form of exemplary. The values that have been standardized in the form of exemplary become stabilizers that balance and harmonize reason that gives birth to intellectual creativity and heart that gives birth to peace and piety. Moral coaching based on the religious / divine values of the Almighty will guarantee the use of knowledge for the benefit of all humanity, and this is what is expected by this beloved country education.

d. A healthy environment

The environment has a very large influence in shaping morals. Therefore, educational institutions, especially universities, carry great moral responsibility, not only to appear exemplary, but also to act as filters that screen and select values and behaviors that are not in line with the values and measures agreed upon by our society.

We have been accustomed to, even doing the conditioning regarding matters that are not in line with our values. Theologians and moralists warned: something good when it has rarely done, then it can be judged by the general public as well, otherwise something which is not good when it has often done, then it can be judged by them as something good. It may not be wrong now to say that the habits that we do are not in line with our desires to form commendable morals. Habits that occur in society have created an impetus for the birth of morals that are not in line with our identity as a religious nation and the philosophy of Pancasila. Look and hear what is displayed in our media, read and see what it serves. Generally, student fights, sadistic killings, sex and rape (even from the teacher and clerics), persecution, corruption, to throwing responsibility and disputing everything as a mistake from past generations.

\section{Implementation of the method of interpretation and the building morals on the moral verses}

a. Analysis of the method of interpreting and building morals in QS. Al-Hujurat [49]: 15 
"Those who believe are only those who believe in Allah and His Messenger, then they did not hesitate and they fought (strove) with their wealth and soul in the way of Allah. They are the right people."

When M. Quraish Shihab will interpret the verses of the Qur'an in his Tafsir Al-Misbah, firstly, he started writing verse texts in Arabic, and followed by their version in Indonesian itself. Then, they are proceed with the interpretation which has its own style. Then they are related to the previous verse, in order to obtain the correlation of the harmony of the message and the understanding between verses. In this connection, he said:

The last verse rebuked the Bedouins who claimed to believe even though their faith was not yet solid. The verse above explains who is truly perfect in his faith and interpretation. Allah says: verily the perfect believers of his faith are only those who believe in Allah believing in His attributes and witnessing the truth of His Messenger in all that is conveyed then even though it continues a prolonged period, their hearts are not touched by doubt even though they experience various tests and disasters and besides their spiritual nature they also prove the truth of their faith through jihad which is fighting for the truth by sacrificing their property and soul in the way of Allah, they are the ones who are right in their words and deeds.

In two verses after the verse above, s. al-Hujurat [49]: 16 and 17 even M. Quraish Shihab explained about faith clearly. In verse 16 it is interpreted that faith does not need to be proclaimed, because Allah is omniscient. ${ }^{12}$

Sayyid Qutb ${ }^{13}$ at length underlined the gift of faith in the following verse (s. Al-hujurat [49]: 17). The nature of this gift (faith) is often not realized by many people, and may even be temporary believers. Faith is the greatest blessing that Allah has bestowed on his servants in this world, he is greater than the favors that Allah has bestowed upon someone with various gifts related to existence such as sustenance, health, life and pleasure. Faith is pleasure which makes human form a unique essence and gives it an important role in this system of the universe. The first thing offered by faith to humans at the time that faith is solid is essentially the heart is the breadth of insight into this form and the relationships of the believer with nature and its role in it.

\footnotetext{
${ }^{12}$ M. Quraish Shihab, Tafsir al-Misbah, (Jakarta: Lentera Hati), Vol: 13, 266.

${ }^{13}$ Ibid., 268.
} 
1) Analysis Method

The surah Al-Hujurat lies in the 49th row of letters in accordance with the order and orderly Uthmani Mushaf. The verses that are the priority of this study are verse 15 from the surah al-Hujurat which examines morality as one of the prophetic missions of the Prophet Muhammad for all mankind.

After M. Quraish Shihab explained the text of the verses and the translation are based on his own version, some of the verses interpreted the Qur'anic concept of true faith itself. Then, he explained the verse with the previous verse, then explained some of the vocabulary that are considered important, and proceeded with interpreting verse by verse in detail and at length, in accordance with the order of the verses in the letter. This means that when viewed from the interpretation, it includes the category of tahlily method and in terms of how to explain it using the ithnaby method.

The method of building morals in morals verses above using method of soul process, exemplary that be reflected in his every behavior both his willingness to struggle and to sacrifice for both property and life for the sake of the religion of Islam and it is only Allah as the orientation of his actions.

\section{2) Concept of M. Quraish Shihab Moral Education}

The education concept of attitude unto Allah Almighty in the above verse is true faith. As for the figure of Uswah Hasanah is the prophet Muhammad saw. To be able to have noble character in accordance with the guidance of the Qur'an, it must be guided by the Messenger of Allah because he has good qualities that must be emulated and be a guide for his people.

b. QS: Al-Nur [24]: 27 and 58

Al-Nur: 27: "O ye who believe, do not enter a house that is not your house before asking permission and giving greetings to its inhabitants. That is better for you, so you (always) remember."

In the ethics of requesting permission, Islam emphasizes that when they are at the door, visitors should not direct their eyes directly to the door, let alone see from the door opening, but it should be in the right or left of the door, to avoid direct view. Because it may be at that time, the residents of the house are in a state that is not pleasing to others. 
On the other hand, in introducing himself, the Prophet taught that if someone is asked who is knocking or asking permission, then he should not answer "me". This is because the word does not reflect who entered.

1) Method Analysis

Method of Tafsir bi al-Ma'thur is used in explaining the interpretation of the verse above, namely by mentioning the hadits of Asbab al-Nuzul of this verse. The difference in the way to explain in this verse with the above verse, M. Quraish Shihab, mentions the opinion of Imam al-Biqa'i, which is indeed widely quoted in this interpretation. Sabab nuzul this verse is: narrated that this verse came down regarding the complaint of a woman Ansar who said: "O Messenger of Allah, I am at home in a state of reluctance to be seen by someone, not father and not child. Then my father came in to see me. And when he was still at home, someone came back to the family, while I was still in the original state (not ready to meet someone), then what should I do? "Now answer the complaint, this verse comes down. ${ }^{14}$

Themethod is tahlily also very coloring when reviewing the interpretation of this verse. In this moral verse interpretation, this verse does not mention how many times permission and greetings must be made before returning. But some hadith give instructions for asking for permission and greetings maximum three times. Besides that, it is also mentioned here that the verse above only prohibits entering someone else's house without permission, but Islamic ethics requires that anyone still ask permission or give a signal about his arrival - even though his own house, even though it is the same as his own partner (husband or wife).

Once the importance of moral education so that the creation of harmonious environmental conditions, serious efforts are needed to instill these values and intensively and it starts the smallest community, the family.

2) Moral Concept

The moral concept of Quraish Shihab when visiting is to maintain the privacy of the host and not to disturb the owner of the house, so that the detailed hospitality of the host has been explained since coming to hold the view.

As in the sura al-Nur: 58: "O you who believe, let the slaves (male and female)

\footnotetext{
${ }^{14}$ M. Quraish Shihab, Tafsir al-Misbah: Pesan, Kesan dan Keserasian al-Qur'an, (Jakarta: Lentera Hati) Vol. 9, 319, lihat juga A. Mudjab Mahalli, Asbab al-Nuzul (Studi pendalaman al- Qur'an), (Jakarta: raja Grafindo), 618
} 
you have, and those who have not been among you, ask for permission from you three times (in one day) Namely: before the morning prayer, when you take off your (outside) clothes in the middle day and after prayer Isha '. (That's) three 'awrah to you. there is no sin against you and no (also) over them other than (three times). they serve you, some of you (there is a need) to some (others). Thus God explains the verses for you. and Allah is All-Knowing, All-Wise. "

This verse is one verse that directs people to social norms in the family. This is an order for parents to educate their children and subordinates to pay attention to social norms. Small children in the house, as well as slave servants (as well as servants - even though they cannot be equated as slaves) often come in and gather with family members at home. Thus, there is an opportunity for parents and masters to avoid being seen by others what is considered secret and inappropriate. In addition this verse also contains recommendations to family members to wear appropriate clothing when meeting each other, so that their dignity, honor and ethics are maintained.

1) Method Analysis

The interpretation method used in the paragraph above is theinterpretation method tahlily, while the method of moral formation uses the method of mental exercise, habituation and a healthy environment.

2) Moral Concept

'Aurat is something that cannot be seen. In order to safeguard the heart and the creation of a life of mutual respect, it is fitting that the closeness between one member and another member should not heed the individual's etiquette in behaving in the house itself. "

c. Q: S: al-Ahzab: 53

"O people those who believe, do not enter the houses of the Prophet unless you are permitted to eat without waiting for the time to cook (the food), but if you are invited then enter and when you finish eating, go out without being preoccupied with extending the conversation. Lo! Such a thing will disturb the Prophet, and the Prophet will be ashamed of you (to send you out), and Allah is not ashamed (to explain) the truth. if you ask them for something (the wives of the Prophet), then ask from behind the veil. this way is more sacred to your heart and their hearts. and you may not harm 
(the heart) of the Messenger of Allah and not (also) marry his wives for ever after his death. Surely this action is great ( $\sin )$ by Allah."

1) Analysis Method

The interpretation method used in the paragraph above is the tahlily and maudhu'i method. This verse contains two basic guidelines. First the ethics of visiting the prophet (house) and the second concerning the hijab. The first part of this verse according to the companions of the Prophet SAW, Anas Ibn Malik, may be related to the marriage of the Prophet SAW, where the Prophet SAW entered Aisha's room and went out, hoping that the remaining guest had returned, but not yet, he entered again to the room of another wife, and so on went in and out of the rooms of all his wives. Finally they came out after a long time the Apostle SAW waited. Anas Ibn Malik, who said this story said: "then I conveyed this to the Prophet SAW. Then he entered. I will go in at that time but the veil has been installed between me and him, then this verse comes down."

This verse shows how noble the morality of the Prophet Muhammad SAW he was ashamed to drive guests away, even though their presence disturbed him. Actually if the guests understood, it was enough for them to see the Prophet stand and go in and out of the rooms, this was enough as a sign that they would go home.

2) Moral Concept

The moral concept offered by M. Quraish Shihab in his interpretation positioned the Prophet as a uswatun hasanah (good exemplary) in which the prophet is central to the perpetrators of the Qur'an itself tends to be gentle and gentle in all his actions even in the face of unpleasant conditions. And also included in matters that greatly interfere with his privacy in his association in visiting as mentioned above. This is also consistent with the principle of moral education which in teaching must have an element of affection Q. S: Luqman [31]: 12. The method used is exemplary methods, mental processing, healthy moral formation environment.

\section{CONCLUSION}

Based on the results of the research described, it can be concluded that: (1) In elaborating his thoughts on moral verses, M. Quraish Shihab is more likely to use the method Tahlily in interpreting the content of the verse. The ability of high Arabic 
language is very visible when discussing the meaning of words in the Qur'an. This work is also rich in references, so the discussion is very broad and detailed, but still in the corridor needed by an interpretation. (2) The concept of M. Quraish Shihab's moral education departs from the concept of human nature. Humans are caliphs on earth whose main task is to worship. And the purpose of human education is based on the human task itself. The education goal is obedience unto Allah in line with the goal of creating human being explained by Al-Qur'an: "I never create human being and genie except to make final purpose or result of all activities as obedience to Me." In M. Quraish Shihab's opinion, the education is really moral. The education is a most important for the advance and the great moral of country. While, moral education itself is a process of orientation, habituation, understanding, teaching, building, ownership and comprehending the target moral values in order to have mental attitude and personality based on the wanted moral values. Therefore, the components of moral education according to M. Quraish Shihab's point of view can be concluded as follows: (a) The goal of moral education is achieving the goal of creating human being as a chaliph of Allah SWT in the world; (b) The method of learning used in delivering moral education is soul process method, habituation, exemplary, and health environment.

\section{E. REFERENCE}

Abdullah, M. Amin. Antara al-Ghazali dan Kant-Filsafat Etika Islam. Bandung: Mizan, 2002.

Arifin, M. Ilmu Pendidikan Islam. Suatu Tinjauan Teoritis dan Praktis Berdasarkan Pendekatan Interdisipliner), (Jakarta: Bumi Aksara, 1994.

Baidan, Nasaruddin. Metodologi Penafsiran al-Qur'an. Yogyakarta: Pustaka Pelajar Offset, 1998.

Drijarkara, N, SJ. Percikan Filsafat. Jakarta: PT. Pembangunan, 1978. Farmawi (al). alBidayah.

Ghazali (al). Ihya'u Ulum al-Din, Juz 1, Mash-hadul Husaini, tt. Ihya'u Ulum al-Din, Juz III.Beirut: Dar al-Fikr, tt. Kitab al-Arba'in fi Usul al-Din.Kairo: Maktabah al-Hindi, tt Hadi, Sutrisno. Metodologi Research I. Yogyakarta: Andi Offset, 1973. http://s0.wp.com/wp.content/themes/h4/global css? M: 12917492589 
Ma'luf, Luis. al-Munjid fi al-Lughah wa al-A'lam. Beirut: Beirut: Dar al- Maghrib, 1986.

Madjidi, Busyairi. Konsep Kependidikan Para Filosof Muslim. Yogyakarta: al- Amin Press, 1997.

Mahalli, A. Mudjab. Asbab al-Nuzul.Studi Pendalaman al-Qur'an. Jakarta: Raja Grafindo.

Mansur. Pendidikan Anak Usia Dini dalam Islam. Yogyakarta: Pustaka Pelajar, 2005.

Muhaimin. Rekon struksi Pendidikan Islam. Jakarta: Raja Grafindo Persada. Muhaimin dkk. Ilmu Pendidikan Islam. Surabaya: Al Kautsar, 1999.

Mundhiri (al), Abd al-'Azim ibn 'Abd Qawiyy Abu Muhammad, at-Targhib wa al-Tarhib min al-Hadith al-Sharif, Juz 3. Dar al-Kutub al-'Ilmiyyah, 1417.

Nata, Abuddin. Akhlak Tasawuf.Jakarta: Raja Grafindo Persada, 1996.

.Filsafat Pendidikan Islam. Jakarta: Logos Wacana Ilmu, 1997.

.Tafsir Ayat-Ayat Pendidikan. Jakarta: Raja Grafindo Persada.

.Tokoh-Tokoh Pembaruan Pendidikan Islam di Indonesia. Jakarta: Raja Grafindo Persada).

. Tokoh-Tokoh Pendidikan Nasional, Jakarta: Gema Insani. P \& K Mesir. alMurshid fi Din al-Islam. Mesir,1952.

Poerwadarminta. WJSKamus Besar Bahasa Indonesia. Jakarta: Balai Pustaka: 1993.

Ramayulis. Ilmu Pendidikan Islam. Cet. III. Jakarta: Kalam Mulia, 2002. Saibani (al), Ahmad ibn Hanbal Abu 'Abd Allah. Musnad al-Imam Ahmad ibn

Shihab, M Quraish. Jilbab: Pakaian Wanita Muslimah.Jakarta: Lentera Hati.

. Membumikan al-Qur'an, Fungsi dan Peran Wahyu dalam Kehidupan Masyarakat, cet XIII. Bandung: Mizan, 1996.

. Menabur Pesona Ilahi.Jakarta: Lentera Hati, 2006.

- Tafsir Al-Mishbah: Pesan, Kesan dan Keserasian al-Qur'an, Vol 1. Jakarta: Lentera Hati, 2007.

. Tafsir Al-Mishbah: Pesan, Kesan dan Keserasian al-Qur'an, Vol 9. Jakarta: Lentera Hati, 2007.

. Tafsir Al-Mishbah: Pesan, Kesan dan Keserasian al-Qur'an, Vol 13. Jakarta: Lentera Hati, 2007.

. Tafsir Al-Mishbah: Pesan, Kesan dan Keserasian al-Qur'an, Vol 15. Jakarta:

Lentera Hati, 2007 
- Wawasan al-Qur'an.Tafsir Maudhu'i atas pelbagai Persoalan Umat. Jakarta: Mizan.

Siba'i (al), Bayumi, et al. al-Adab wa al-Nusus.Kairo: Dar Nahdat Mishr, tt. Surachmad, Winarno dan Sutrisno, Hadi. Pengantar Interaksi Belajar Mengajar Dasar dan Teknik Metodologi Pengajaran. Bandung: Tarsito, 1976. 